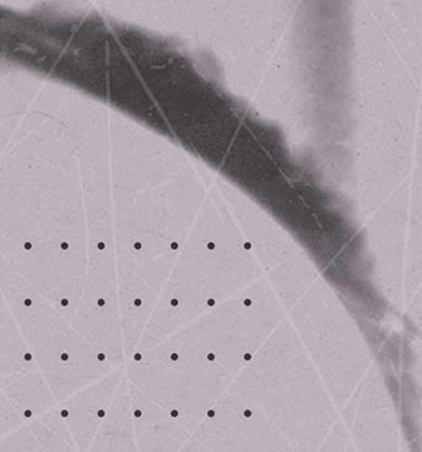

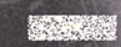
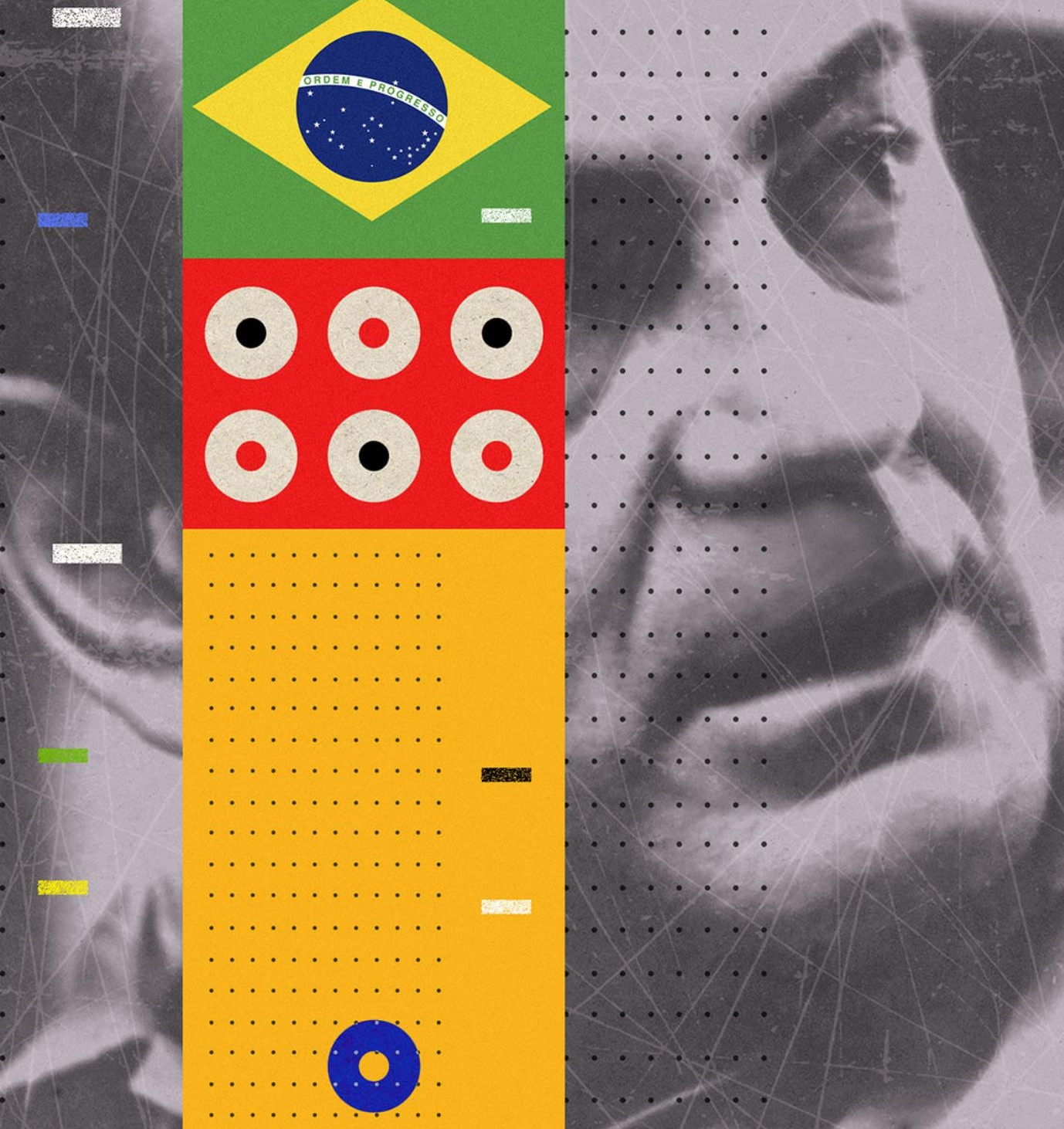


\title{
O nacional-desenvolvimentismo de Hélio Jaguaribe: nacionalismo, ideologia e classes sociais
}

\author{
The national-developmentalism of \\ Hélio Jaguaribe: nationalism, ideology \\ and social classes
}

\author{
Helio Cannone* | Hugo Müller**
}

\begin{abstract}
Resumo
$\mathrm{O}$ artigo pretende-se um esforço de intepretação da produção do cientista político Hélio Jaguatibe, tendo como foco o período em que atuou no Instituto Superior de Estudos Brasileiros (ISEB). A partir de metodologia contextualista, pretendemos inserir as ideias do autor em sua época para entender quais eram os problemas que ele se deparava e, assim, melhor compreender sua inserção nestes debates. A partir de obras escritas nos anos 1950, serão privilegiadas suas ideias acerca do nacional-desenvolvimentismo, papel do nacionalismo no Brasil e sua interpretação sobre Ideologia, classe sociais e democracia no país.
\end{abstract}

Palavras-chave:nacional-desenvolvimentismo;ISEB; burguesia nacional; nacionalismo; ideologias políticas.

\begin{abstract}
The article intends to try to interpret the production of political scientist Hélio Jaguatibe, focusing on the period in which he worked at Superior Institute of Brazilian Studies (ISEB). Based on contextual methodology, we intend to insert the author's ideas in his time to understand what were the problems he faced and, thus, better understand his insertion in these debates. From works written in the 1950s, his ideas about national developmentalism, the role of nationalism in Brazil and his interpretation of ideology, social class and democracy in the country will be privileged.
\end{abstract}

Keywords: national-developmentalism; ISEB; national bourgeoisie; nationalism; political ideologies

\footnotetext{
* Candidato a Doutor em Ciência Política, Institiuto de Estudos Sociais e Políticos, Universidade do Estado do Rio de Janeiro, RJ, Brasil. https://orcid.org/0000-0002-8774-4197. E-mail: helio.cannone@gmail.com

** Candidado a Doutor em História, Universidade do Estado do Rio de Janeiro, RJ, Brasil. https://orcid.org/0000-0002-9498-5685. E-mail: hugomuller.rj@gmail.com
} 


\section{INTRODUÇÃO}

Este trabalho consiste em um esforço de interpretação sobre o pensamento nacionalista de Hélio Jaguaribe. Serão discutidas as singularidades e as raízes do conceito de nacionalismo forjado por Hélio Jaguaribe, as aproximaçóes e divergências com outros intelectuais-públicos da época. Como recorte, os anos de Jaguaribe à frente do IBESP e do ISEB, ou seja, de 1952 a 1958, serão nossas balizas cronológicas. Identificamos neste período o ápice na História do Brasil da germinação projetos nacionalistas associados a ideia de desenvolvimento. $\mathrm{O}$ artigo se divide em quatro partes, após esta introdução, iremos apontar a pluralidade dos pensamentos nacional-desenvolvimentistas nos anos 50, inserindo a contribuição de Jaguaribe em contramão ao desenvolvimentismo de outros atores políticos eintelectuais do período. A fim de cumprir nosso objetivo, iremos ao longo do artigo expor nossas discordâncias com parte da bibliografia que compreende o isebiano enquanto um intelectual oficial do projeto desenvolvimentista do Governo JK. Na terceira parte, apresentaremos a concepção de nacionalismo por parte de Hélio Jaguaribe, sua relação com o conceito de desenvolvimento, além de estabelecer um panorama mais geral dos distintos nacionalismos na década de $1950 . \mathrm{Na}$ quarta parte, traremos à baila o alicerce do nacionalismo de Hélio Jaguaribe, sua concepção de história e ideologia e sua visão histórica de classes sociais no Brasil, será o momento oportuno de apresentar ainda algumas recepçóes teóricas do isebiano em questão.

\section{A PLURALIDADE DO NACIONAL-DESENVOLVIMENTISMO}

A historiadora Sonia Regina de Mendonça em sua obra Estado e Economia no Brasil: Opçóes de Desenvolvimento irá dissertar, ao abordar o governo JK, sobre o papel do ISEB na conjuntura econômica e política do país. A autora observa que o debate nacionalista sobre a intervenção estatal, muito forte nos primeiros anos da década de 1950 durante a era Vargas, ganha novos contornos incluindo a questão da participação do capital privado em função da própria integração capitalista do Brasil neste período. Um consenso dos estudiosos que se aprofundam sobre o período é que o nacionalismo não era único, existiam algumas vertentes que eram identificadas enquanto tais. Mendonça estabelece três distinçóes: 1) O nacionalismo neoliberal, que considerava o capital estrangeiro bem vindo para o desenvolvimento e sem a necessidade do controle do Estado, encampado pela União Democrática Nacional (UDN); 2) O nacionalismo radical, que rejeitava a participação do capital estrangeiro na industrialização do país acusando um aprofundamento da subordinação aos Estados Unidos, compartilhado pelo 
PCB e setores do PTB; 3) O nacionalismo-desenvolvimentista, que propunha a entrada de capital estrangeiro com a participação do Estado, o governo de Juscelino Kubitschek, o ISEB e a burguesia industrial compunham essa vertente (MENDONÇA, 1999, p. 60).

Ao dividir os nacionalismos com o objetivo de diferenciá-los, a autora acaba colocando correntes distintas sobre o tema dentro da mesma categoria de "nacionalismo-desenvolvimentista", assim como a inclusão da UDN e dos adeptos do liberalismo como um tipo de nacionalismo torna-se controverso ${ }^{1}$. Sob esta última questão, a historiadora parte de uma premissa correta de que na época ninguém se intitulava "antinacionalista”. Porém, é necessário irmos além das auto intitulaçôes de setores em disputa na época e analisarmos a capacidade desses grupos serem, minimamente, legitimados eaceitos em sua própria contemporaneidade. Jaguaribe irá comentar em sua obra Nacionalismo na atualidade brasileira que nos debates políticos da época o campo progressista criou a pecha de "entreguista" para os setores mais liberais. De fato, mais além das adjetivaçôes dos setores progressistas, a ala conservadora com ideias liberais na economia não havia produzido qualquer identificação bem sucedida enquanto nacionalistas para a sociedade, pelo contrário, o nacionalismo foi muito associado pela UDN ao totalitarismo. Se antes da II Guerra Mundial, Getúlio Vargas foi diversas vezes acusado de práticas fascistas, após o fim da guerra o comunismo foi fortemente vinculado às pretensões totalitárias, e muitas vez tal vínculo foi estendido para outros setores progressistas. Carlos Lacerda, célebre udenista, irá afirmar em 1962 que refutava o nacionalismo por colocar a nação acima do indivíduo, ele acreditava que seu partido não era nacionalista e foi taxativo sobre o tema: "O nacionalismo moderno é um fator de guerra e de conflitos. Serviram-se do nacionalismo, o nazifascismo ontem; e o hoje, o comunismo." (LACERDA, 1965, p. 91).

César Guimarães circunscreve o nacionalismo no Governo Vargas enquanto "uma economia planejada 'além da conta' e de uma política externa independente” (GUIMARÃES, 2001, p.151) e vai compreender que no pós-guerra houve uma ressignificação do termo relacionando-o à descolonização e ao fortalecimento de "economias frágeis" do terceiro mundo. Sendo, em termos genéricos, o nacionalismo na década de 50 compreendido através um "protecionismo e estatismo". Se considerarmos também os critérios de Pedro Fonseca (2015) existiriam três características fundamentais do pensamento desenvolvimentista. A primeira seria a existência de um projeto nacional, descrito por ele como "um projeto deliberado ou estratégia tendo como objeto a nação e seu futuro" (FONSECA, 2015, p. 7). As outras duas a ela somadas seriam a intervenção estatal consciente e deliberada - planejamento 
- e a compreensão de que a industrialização seria o caminho mais adequado para superar o atraso econômico, político e social tal como percebido pelos teóricos e atores políticos. Para o autor são igualmente pressupostos fundamentais a intencionalidade na defesa destes três pontos e que ela seja feita dentro dos marcos de uma economia capitalista.

Ao partirmos dessa definição de Guimarães e de Pedro Fonseca sob a luz da conjuntura histórica da época, identificamos dois problemas nas divisões sobre o nacionalismo realizado por Mendonça. O primeiro consiste numa inclusão equivocada da UDN enquanto nacionalista ao categorizar uma vertente de "nacionalismo neoliberal". O segundo problema trata-se da dilatada composição do intitulado "nacionalismo-desenvolvimentista", colocando diversos setores pensantes da sociedade sob o mesmo signo, e, além disso, todos responsáveis e atrelados às realizaçôes do Governo JK. Em sentido contrário, temos que fazer o exercício de tratar o desenvolvimentismo e o nacionalismo enquanto categorias diferentes e entender que o termo "nacional-desenvolvimentismo" foi utilizado enquanto bandeira política de diversas formas e por diferentes grupos que alcançaram ou não o Estado. Exemplo disto se dá na diferença entre o que defendiam teóricos reunidos em torno do ISEB e da ESG. Embora ambos se encaixam no conceito de desenvolvimentismo de Pedro Fonseca, o projeto político-econômico dos dois think tanks tinham diferenças fundamentais. Nas produçóes de Hélio Jaguaribe, veremos que a sua caracterização de desenvolvimento será utilizada para "qualificar" o nacionalismo por ele defendido diferenciando-o dos demais.

$\mathrm{Na}$ referida obra de Mendonça existe um grande esforço para atrelar as formulações isebianas aos planos de desenvolvimento do Governo de Juscelino. O argumento "forte" da autora consiste em apontar a semelhança de um determinado discurso público de $\mathrm{JK}$ com as definiçóes gerais dos objetivos do ISEB (MENDONÇA, 1999, p. 64). A autora chega a fazer a ressalva de que não havia um consenso sobre o modelo de desenvolvimento ideal dentro do ISEB, principalmente sobre a utilização do capital estrangeiro, porém, em contrapartida afirma que a linha do nacionalismo "moderado" de Hélio Jaguaribe prevaleceu no Instituto. Tal afirmação é inconsistente já que a publicação da obra de Jaguaribe $O$ nacionalismo na atualidade brasileira, na qual expõe sua versão do nacionalismo brasileiro, tornou-se polêmica dentro e fora do ISEB, tornando-se o pivô de sua saída. Porém, a despeito desta questão, há um ponto central em que divergimos da autora: as formulaçôes de desenvolvimento do ISEB e especificamente do Hélio Jaguaribe não foram assumidas pelo governo de Juscelino Kubitschek. Realizar tal referência trata-se de uma leitura superficial sobre o Instituto. 
Ressaltaremos alguns aspectos que demonstram que a ideias de Hélio Jaguaribe não se concretizaram em políticas públicas no período juscelinista. Primeiro, o conceito de desenvolvimento nacional formulado por Jaguaribe previa um planejamento amplo que ia para além da economia. $\mathrm{O}$ isebiano via com bons olhos os esforços de medidas econômicas que foram empreendidos por Dutra e Vargas em seu último governo, levando a uma série de estudos e levantamentos de dados úteis, assim como o Plano de Desenvolvimento do então presidente Juscelino Kubitschek para o quinquênio. Porém, o autor apontava a necessidade de tal plano quinquenal se transformar de fato em planejamento econômico com um grau de "integração e sistematicidade". Para além do planejamento econômico prioritário, Hélio Jaguaribe defendia a extensão para outras áreas, como a educação, saúde, a relação entre classes sociais e o estatuto do trabalho, assistência social e funcionamento dos aparelhos estatais. Sendo assim, o autor adotou uma visão mais ampla, na qual outros setores da nação deveriam estar inclusos neste projeto de desenvolvimento. Esta perspectiva de tratar o desenvolvimento nacional desde uma visão que integra diversas áreas da sociedade retoma uma perspectiva "mannheimiana”, que privilegia a posição do intelectual que esteja num lugar epistemológico acima de setores e áreas sociais específicas sendo capaz de mobilizar interesses gerais da sociedade.

[...] o planejamento brasileiro, transcende, duplamente, a área do meramente econômico, quer pelo fato de o desenvolvimento ser uma categoria que se refere a uma estrutura-tipo de uma comunidade, desta forma abrangendo todos os aspectos da vida social [...]. (JAGUARIBE, 1979, p. 212).

No ensaio "A crise Brasileira" do próprio autor, publicado no Cadernos de Nosso Tempo, em 1953, Jaguaribe já indicava a amplitude do que estava em crise: "A crise brasileira [...] se desenvolve em todas as profundidades e em todos os setores da vida nacional" (JAGUARIBE, 1981, p. 132). Portanto, a solução da crise brasileira de tamanha extensão necessitava um planejamento amplo. De tal forma que o escritor isebiano irá incluir temas de envergadura nacional em sua análise acerca do desenvolvimento, como as classes sociais e suas respectivas ideologias.

O Programa de Metas, conhecido enquanto Plano de Metas foi um programa de desenvolvimento econômico do governo Juscelino Kubitschek. Ele teve como base os diagnósticos realizados pelo Grupo CEPAL-BNDE que estudou as demandas da economia brasileira e contou também com grande influência da Comissão Mista Brasil-Estados Unidos.

O Plano tinha como objetivo maior elevar o padrão de vida dos brasileiros e constituía-se de projetos de desenvolvimento que se dividiam em cinco grandes 
setores: energia, transportes, indústria de base, alimentação e educação. Cada um dos setores estava dividido em metas, que totalizavam 30. Era ainda parte do Plano a construção de Brasília, cujos projetos de transporte estavam especialmente articulados. (CAPUTO \& COSTA, 2009, p. 375).

A pretensa extensão do Plano tinha, na realidade, como enfoque a área essencialmente econômica. Os efeitos do programa em outras áreas se deram principalmente através das alterações do padrão econômico do país e não através de políticas públicas específicas. A principal exceção foi a criação da Superintendência do Desenvolvimento do Nordeste (SUDENE) idealizada por Celso Furtado, já no final do Governo JK em 1959.

Dentro da área econômica, Jaguaribe teve uma crescente preocupação com o papel do Estado no controle do planejamento econômico e para evitar os chamados "grupos de pressão", ou seja, a interferência indevida da iniciativa privada nos assuntos públicos. O modelo de desenvolvimento econômico defendido por Hélio Jaguaribe tinha como condição fundamental a constituição de uma indústria de base, capaz de produzir bens de produção que na situação cambial em que se encontrava o país era impossível de se obter através de importaçóes. Tal fato geraria um equilíbrio na balança comercial brasileira. $\mathrm{O}$ intelectual propunha a necessidade de uma economia capaz de "organizar e disciplinar o sistema produtivo do país" (JAGUARIBE, 1981, p. 200).

Hélio Jaguaribe constatou que a ausência de capitais nacionais aliados às novas condições de investimentos estrangeiros fazendo com que os investimentos não tendessem a serem realizados segundo critérios de maior essencialidade, além do mais, devido à crise estrutural não se permitia um rompimento do país com a então atual crise econômica. Esse diagnóstico, que em síntese apontava que o capital de forma espontânea não teria capacidade de superar a crise, seria fundamental para um ponto central da proposta de desenvolvimento econômico de Hélio Jaguaribe: a intervenção estatal.

[...] a modificação das condições produtivas exige uma intervenção planificadora do Estado que, direta ou indiretamente, organize a economia do país para os fins em vista, estimule ou desestimule determinadas atividades, coordene os fatores, discipline os investimentos e assuma, promocional ou supletivamente, certos encargos produtivos. A intervenção planificadora, promocional e supletiva do Estado constitui, assim, a primeira das condiçóes necessárias para que o impasse crescimento econômico-desequilíbrios estruturais seja vencido sem prejuízo do desenvolvimento econômico. (JAGUARIBE, 1981. p. 201).

Jaguaribe considerava fundamental manter um “ajustamento" entre o plano econômico e o mercado. Para tal, era importante manter uma autonomia do planejamento dentro da economia como um todo. O isebiano alertava 
para uma tendência do livre mercado alterar os setores planejados da economia ao passo que isso levaria a uma solução de efetuar um planejamento total da economia. Ambos os casos, segundo o autor, poderiam ser evitados no Brasil. O autor defendia que a modalidade deste planejamento poderia ser baseada através do induzimento, de maneira que os agentes públicos e privados respeitassem os termos do plano. Ao se perguntar quais sãos as áreas da economia no Brasil que deveriam ser inseridas no planejamento econômico, o autor cita a fase em que o país se encontrava e sua estrutura-tipo, na qual a prioridade era "assegurar as ótimas condiçóes para o desenvolvimento econômico-social”. Hélio Jaguaribe, ao traçar o objetivo maior em que "o país deve assumir um destino próprio e afirmar-se como comunidade independente e autônoma”, aponta que a metas necessárias a curto e médio prazo teriam um caráter de "univocidade" independe do viés ideológico (JAGUARIBE, 1981, p. 211-212). Assim sendo, o intelectual acreditava ser impreterível uma reforma do Estado, que deixasse de ser obsoleto para o desenvolvimento tornando-se funcional e não mais ser vulnerável aos "grupos de pressão" de interesses privados, o Estado obsoleto e vulnerável era qualificado pelo autor enquanto um "Estado cartorialista". Por outro lado, o governo JK foi marcado de fato pela participação efetiva do Estado na industrialização do país através de um plano de desenvolvimento que associava a indústria nacional ao capital estrangeiro. Como aponta Sônia Draibe em sua obra Rumose Metamorfoses: Estado e industrialização no Brasil (1930-1960):

[...] o Estado definiu um conjunto integrado de investimentos e assegurou as condições mínimas de financiamento, estendendo ao limite o seu poder de regulação e capacidade fiscal e financeira. A profundidade alcançada pela internacionalização da economia foi definida nos marcos da relação - aparentemente paradoxal - entre o empresariado nacional e o Estado. (DRAIBE, 2004, p. 225).

Desta forma, apontamos que dentro do que Sonia Regina de Mendonça qualifica enquanto "nacionalismo-desenvolvimentista” há muitas diferenças que tornam de difícil aceitação esta categoria proposta para designar um determinado tipo de nacionalismo. A partir do pressuposto de que Hélio Jaguaribe e o ISEB foram ideólogos do desenvolvimentismo que se realizou, a autora irá tratar a malograda tentativa de industrialização autônoma e a sua formulação intelectual nos termos de "mascaramento" da industrialização associada ao capital estrangeiro. Portanto, para a autora, o ISEB, assim como outros setores do nacional-desenvolvimentismo, era instrumento da burguesia industrial que "obscurecia [...] o papel político desempenhado pelos empresários industriais, dando margem a uma visão distorcida sobre suas articulações políticas com as empresas estatais e as multinacionais" (MENDONÇA, 1999, p. 61). O caminho que adotamos aqui foi o de situar as 
ideias de Hélio Jaguaribe em seu contexto para destacar como ele se valeu da linguagem do desenvolvimentismo para propor soluçôes específicas para o desenvolvimentos nacional.

\section{O NACIONALISMO EM HÉLIO JAGUARIBE}

Para melhor entender no que consistia o nacionalismo de Hélio Jaguaribe e sua relação com o conceito de desenvolvimento, é preciso colocá-lo em quadro mais amplo, tanto internacional quanto doméstico. Dentro do primeiro cenário, é fundamental destacar a mudança na condução das políticas econômicas mundiais no período pós II guerra mundial. A perspectiva de um Estado ator, que coordenasse as atividades produtivas e promovesse o bem-estar social ganharam força. Tal como destaca Fiori (1999), os EUA saíram pouco afetados do conflito bélico e, impulsionados pela nova competição geopolítica, agora com a União Soviética, o país se tornou credor da Europa através do plano de reestruturação das economias afetadas - conhecido como Plano Marshall. No ambiente doméstico norte-americano, o Estado foi impulsionador fundamental das atividades tecnológicas, com o fim de fazer frente à potência socialista. Enquanto isso, nos países da Europa Ocidental, o entendimento da ampliação do papel do Estado em questôes econômicas e sociais é compartilhado através do conceito de planejamento. Em dados trazidos pelo historiador britânico Tony Judt (2007), em maior de 1946 um quinto da capacidade industrial francesa pertencia ao Estado.

No caso de países do sul-global, César Guimarães (2001) afirma que estas "ideias-força” foram recepcionadas a partir do conceito de desenvolvimento. Por sua vez, este era visto pelos movimentos decoloniais na África e na Ásia como forma de reparar assimetrias internacionais, permitindo através da afirmação de uma cultura e de uma administração política centrada em seus interesses locais, a expansão das benesses da socialdemocracia para regióes vistas como periferia do mundo. Segundo frase do mesmo autor: "[...] descolonização, nacionalismo econômico, planejamento são nomes da esperança” (GUIMARÃES, 2001, p. 158).

Dentro deste contexto maior, o Brasil compartilhava desta busca pelo desenvolvimento como forma de superar seu "atraso" frente ao Ocidente. $\mathrm{Na}$ História nacional, este movimento já era sentido como em curso desde a revolução de 1930 . Para Wanderley Guilherme dos Santos o evento que encerrou a Primeira República teria sido um "divisor de águas" (SANTOS, 1970 , p. 20) no pensamento político brasileiro. A partir dele, teriam começado a ganhar força pautas de uma tradição que o autor chama de nacionalista. Dentre suas características estariam uma visão dicotômica entre um 
Brasil agrário e um Brasil industrial, a busca de singularidades do país e a crítica a tentativas de transplantação mecânica de ideias estrangeiras. Ainda no Estado Novo, autores como Oliveira Viana e Azevedo Amaral se destacaram como defensores de um modelo de entrada do Brasil na modernidade encabeçado pelo Estado. Nos anos posteriores, o otimismo gerado pelos resultados econômicos do Estado atuante fez com que os mais diversos atores defendessem modelo similar. No entanto, não havia entre eles consenso sobre o significado de nacionalismo e de desenvolvimento

Dentre os centros que se propunham intervir no debate público através da defesa de um ideário desenvolvimentista estava o Instituto Superior de Estudos Brasileiros (ISEB), o qual Hélio Jaguaribe era membro fundador . Segundo Angélica Lovatto (2006) a trajetória do think tank pode ser dividida em três fases: na primeira, iniciada em 14 de julho de 1955, não haveria consenso ideológico; já na segunda, o nacional desenvolvimentismo seria hegemônico e os isebianos estariam preocupados em pensar um projeto a ser encampado pela burguesia nacional; na terceira e última, de 1961 até 1964, a instituição estaria comprometida com a defesa das reformas de base de João Goulart.

Embora fosse um centro especializado na formação de uma ideologia nacional-desenvolvimentista, o ISEB era heterogêneo em sua composição Dentre as diferentes perspectivas estava a do sociólogo e teórico trabalhista Alberto Guerreiro Ramos. Ele compreendia que o trabalhador era espécie de sócio do desenvolvimento nacional e uma força política sem a qual nenhum governo se sustentaria. O intelectual previa uma relação direta entre planejamento econômico do Estado e interesse popular, que vincularia a questão nacional aos interesses dos trabalhadores. Seria necessária ainda uma aliança política entre os setores interessados em soluçôes nacionais para o desenvolvimento do Brasil para que o processo se realizasse. Outra posição relevante dentro do ISEB era a de Nelson Werneck Sodré. Enquanto membro atuante no Partido Comunista Brasileiro (PCB), o historiador via o processo de desenvolvimento de forma similar a de Guerreiro Ramos, no entanto, para ele, a questão se tratava de uma etapa. Percebendo a questão como análoga a uma revolução burguesa, ela seria a condição necessária para atingir-se o comunismo no futuro.

Fora do âmbito do instituto, a Escola Superior de Guerra (ESG) também era locus privilegiado de discussão sobre o nacional-desenvolvimentismo, embora com entendimento deveras diverso da questão. Segundo um dos principais intelectuais da instituição, Golbery de Couto e Silva, o nacionalismo e a necessidade de levar a frente um processo de desenvolvimento estaria conectado a necessidade de manutenção da soberania e da segurança 
nacional. Em sua obra Geopolitica do Brasil (1981) ele critica as outras visões como distorcidas e afirma haver ameaça de invasão do país por ideias comunistas. O remédio seria o fortalecimento do ideal nacional e a garantia de qualidade de vida e subsistência para que setores populares não aderissem a ideais marxistas.

Ponto de discordância fundamental deste autor com Hélio Jaguaribe é no entendimento do lugar do nacionalismo no pensamento desenvolvimentista. $\mathrm{O}$ isebiano defendia um nacionalismo pragmático, como meio para atingir um fim: "O nacionalismo, como se viu, não é imposição de nossas peculiaridades, nem simples expressão de características nacionais. É, ao contrário, um meio para atingir um fim: o desenvolvimento" (JAGUARIBE, 1958, p. 52). Golbery inverte a relação de causalidade, colocando o desenvolvimento a serviço do nacionalismo. Com isso, ele diverge ao mesmo tempo da concepção de Jaguaribe e do ISEB em geral:

O nacionalismo é, portanto, deve ser, só pode ser um absoluto em si mesmo um fim último - pelo menos enquanto perdurar a nação como tal. Lugar não há, nem deve haver, nem poderá haver para o nacionalismo como simples instrumento de um fim que o transcenda, como degrau, apenas numa escala que o transmonte. Isso nunca será nacionalismo - será engano, será burla, será até mesmo chantagem. (SILVA, 1981, p. 99)

A principal obra de intenção de Hélio Jaguaribe no debate foi $O$ nacionalismo na atualidade brasileira, de 1958, escrita na fase nacional-desenvolvimentista do ISEB. Portanto, assim como a obra Para uma politica de desenvolvimento nacional, dificilmente conseguiremos depreender as principais características do pensamento político de Jaguaribe e sua intervenção no acirrado debate desenvolvimentista se passarmos ao largo deste livro. Ametodologia que perpassa o livro tem inspiração em procedimento hegeliano. $\mathrm{O}$ autor entende a história a partir do movimento das ideias vistas por categorias dicotômicas que representariam teses e antíteses. Deste modo, Jaguaribe pretendia propor espécie de síntese dialética do debate sobre o nacional-desenvolvimentismo.

Com o intuito de se posicionar na disputa intelectual sobre o significado desta ideologia, logo no prefácio de seu livro o cientista político aponta que o grande fator que motivou este trabalho foi um panorama por ele diagnosticado de uma grande incompreensão sobre o nacionalismo no Brasil. Tal fato gerava barreiras para a adoção de políticas "racionais" além de radicalismo e "aventureirismo anti-social e antinacional” (JAGUARIBE, 1958, prefácio). O combate às más interpretaçôes sobre o nacionalismo viria através de um trabalho de precisar esta categoria lhe conferindo objetivos claros. Dá-se aí a relevância desta obra, “[...] evitando-lhes que as controvérsias semânticas 
ou as idiossincracias pessoais separem homens e forças que de fato têm os mesmos propósitos e se acham ligados às mesmas solidariedades." (JAGUARIBE, 1958, prefácio). O caráter aglutinador e até mesmo harmônico do nacionalismo será uma das características desenvolvidas pelo o autor. $\mathrm{Na}$ apresentação da obra, conferindo ainda mais importância ao tema, ele afirma que esta categoria traçaria uma "linha divisória" nos mais importantes debates políticos do país, dividindo-os em dois grupos: "nacionalistas" e "entreguistas". Os de segunda categoria, apesar de não se auto denominarem assim, agiriam tentando esvaziar as significações do nacionalismo, caracterizando-o em aspectos negativos, enquanto os primeiros se caracterizariam muito mais em sua oposição do que propriamente dito por características genuínas.

A divergência entre nacionalistas e entreguistas (ou cosmopolitas) teria a ver com a manutenção do antigo regime produtivo do Brasil. Associando os cosmopolitas aos latifundiários, seus quadros políticos e seus intelectuais que, como Eugênio Gudin, defendiam a manutenção das bases agrárias da matriz econômica nacional, Jaguaribe afirmaria que esta corrente defenderia as mesmas políticas econômicas liberais presentes desde o Império até a República. Como antítese desta posição, os nacionalistas prefeririam um dirigismo que favorecesse a industrialização, com políticas protecionistas e de transferência de renda, buscando a soberania nacional. Embora não disfarce sua preferência pelo nacionalismo, oautor queria, acima de tudo, superar as duas correntes. Quando estudou a história da gestão econômica do Brasil, ele reconheceu excesso dos dois lados. A busca de Hélio Jaguaribe pela síntese das ideologias autóctones, o fez concluir que o problema estaria no fato de que ocosmopolitismo subestimaria a capacidade nacional de investimentos e o nacionalismo pecaria pelo oposto. A síntese estaria no equilíbrio.

Desta forma, um esforço de esclarecimento se fazia necessário e urgente no país. Nesta altura, o isebiano condiciona o sucesso do nacionalismo a sua prévia formulação. Oargumento que sustenta tal condicionamento é a explicação de que se trata de um fenômeno que não ocorre "a despeito da consciência dos protagonistas” (JAGUARIBE, 1958, p. 13). Portanto, no sentido de "encruzilhada", o nacionalismo também era uma possibilidade para o Brasil, mas não um destino inevitável. "Daí o dilema [...] ou alcança uma formulação mais consistente [...] e determina o curso subsequente de nossa história, ou malogra [...] a condição mesma de o povo brasileiro realizar uma história nacional”. (JAGUARIBE, 1958, p. 14).

Jaguaribe irá aprofundar a noção de que o nacionalismo antes de uma ideia racional se trata de um fenômeno histórico político, portanto, tal categoria só se pratica se houver condições necessárias na comunidade. Ao 
conferir ao nacionalismo enquanto um produto de fenômenos históricos e sociais, o isebiano retira do indivíduo e de seu voluntarismo acapacidade de exercer naturalmente tal categoria, desta forma, o nacionalismo sai do centro de associaçôes de juízos de valores humanos, como "bem ou o "mal”, e passa a ser tratado em sua dimensão estrutural.

Enquanto fenômeno histórico-social, o nacionalismo surgiria do choque de condiçốes objetivas com condições subjetivas. As primeiras seriam de ordem histórica (estabelecimento de uma Cultura ocidental a partir do Renascimento), sociais (como forma de organização de uma comunidade) e geográficas (fixação territorial). Já as condiçôes subjetivas seriam de ordem cultural: cosmovisão, linguagem, arte, instituiçôes e tecnologia. A Nação se constituiria como tal quando, dadas algumas condiçốes objetivas, o fator subjetivo agregaria a formulação de um projeto de integração nacional. Sem ele uma nação no sentido histórico não se tornaria uma nação no sentido político. O nacionalismo seria aspiração fundadora epreservadora da nacionalidade que, dada as condiçóes objetivas para tal, se constitui como projeto nacional. No sentido que Ortega y Gasset (s.d.) dá ao termo, a Nação e o nacionalismo surgiriam no pensamento de Hélio Jaguaribe como crenças coletivas.

Portanto, Jaguaribe vai apontar que a constituição de uma nação se dará através de um projeto político, que a funde e a mantenha. Para além da solidariedade objetiva de seus membros, a nação necessitaria de um projeto nacionalista - para preservá-la e desenvolvê-la. O isebiano irá nomear essa relação entre as condiçóes objetivas de laços dos povos e o seu projeto político enquanto "dialética da nação". Desta forma, o nacionalismo será preservador da nacionalidade:

A nação, em sentido histórico, precede a nação, em sentido político. Mas nem todas as naçốes, em sentido político. Mas nem todas as nações, em sentido histórico, ou seja, nem todas as comunidades dotadas de unidade de raça e de cultura, habitando o mesmo território "natural", chegam a constituir uma nação. (JAGUARIBE, 1958, p. 21).

$\mathrm{O}$ isebiano distingue o nacionalismo integrador do nacionalismo imperialista. O primeiro teria como propósito promover e preservar uma nacionalidade "historicamente possível", pertenceram a essa categoria os países europeus e os EUA no século XVIII, já no século XX, os países da Ásia, África e América - Latina se encontrariam nesta situação. $\mathrm{O}$ segundo representa um desenvolvimento que já extravasou e superou o seu enquadramento nacional, já plenamente conformada, com um nacionalismo recrudescido, com potencial agressivo para com outros países. Os países europeus e os EUA são membros desta categoria. Jaguaribe disserta sobre a existência de um certo 
tipo de "incompreensão" sobre o nacionalismo integrador por parte das nações imperialistas, pois estas já se afastaram historicamente dessa experiência de integração, e muitas vezes julgam que o nacionalismo integrador é uma ameaça global.

A noção histórica do nacionalismo em Jaguaribe está intrinsecamente ligada ao de desenvolvimento, na qual seria um projeto político integrador da comunidade. Desta forma tal projeto se realiza quando compreendida enquanto uma necessidade.

Às nações européias, em sentido histórico, preexistiram a esse processo integrativo. O simples fato de diversas comunidades falarem a mesma língua, dentro da mesma cultura [...] não conduziu, todavia tais comunidades a integrarem o mesmo ordenamento político jurídico, enquanto tal existência não lhes foi imposta enquanto necessidades vitais. (JAGUARIBE, 1958, p. 28)

Assim sendo, o autor aponta que o projeto nacionalista é deliberado no sentido de exprimir uma decisão política sobre a nação, porém, indeliberado ao ser consequência de necessidades humanas. Desta última premissa o autor relaciona ao humanismo, onde o nacionalismo seria meio para organizaçóes sociais mais elevadas da humanidade, "tem como sentido finalístico a realização de um modelo de humanidade”. (JAGUARIBE, 1958, p. 29).

Ao analisar o desenvolvimento das condiçôes sócio-históricas do Brasil para o nacionalismo se estabelecer enquanto uma possibilidade, os elementos apresentados são os mesmos que dois anos antes o autor utilizou para justificar a viabilidade histórica do desenvolvimento no país, em sua obra Para uma politica de desenvolvimento nacional. Ao longo desta obra de 1958, as categorias de nacionalismo e desenvolvimento nacional vão se aproximando. O autor afirma que desde a década de 1920, movimentos nacionalistas foram aparecendo de forma esparsa e fragmentada, fruto de sua viabilidade sóciohistórica. No campo da cultura o autor cita o movimento modernista de 1922. No campo econômico, o autor identifica também a eclosão de um nacionalismo que reivindica os monopólios estatais da exploração do petróleo e dos minerais. Já na área da política outro nacionalismo surgiu sob a bandeira da justiça social e democracia, além de um fortalecimento da União e uma maior autonomia nas relações internacionais perante os EUA.

O panorama econômico do Brasil permitiu surgir um tipo de nacionalismo em oposição ao cosmopolitismo. Se a economia agroexportadora, trazendo os bens de consumo e as ideias de fora, formara um pensamento cosmopolita, a transformação econômica com a constituição de um mercado interno permitiu o desenvolvimento de do pensamento nacionalista. Em relação à composição social, o cosmopolitismo estava presente na burguesia latifúndio-mercantil e nos setores parasitários da classe média. Já o 
nacionalismo, nos setores mais modernos das classes sociais, ou seja, nos industriais, proletariado, e setores técnicos e intelectuais da classe média. Porém, essa manifestação ideológica do nacionalismo em oposição ao cosmopolitismo é caracterizada por Hélio Jaguaribe enquanto incondicional.

O nacionalismo superestimando a capacidade nacional de investimento e especialmente o preparo tecnológico do país considera com ceticismo ou com receio o investimento estrangeiro e se inclina para uma política de capitalismo de Estado, atribuindo aos poderes públicos, particularmente na órbita da União, o principal encargo de promover o desenvolvimento econômico do país. (JAGUARIBE, 1958, p. 34).

Portanto, se por um lado haveria uma postura que subestimava o Brasil e a capacidade nacional de desenvolvimento, recorrendo essencialmente ao capital estrangeiro, por outro lado, o nacionalismo era incondicionalmente contra o regime de capital estrangeiro no país. Desta forma, mais do que representar uma ideologia autêntica, ambas acabam pendente para a ideologia de suas classes.

A pura e simples afirmação de confiança nas potencialidades do país e o sentimento de auto-suficiência, não controlados criticamente pela consciência das limitaçóes nacionais e pro critérios comparativos, conduz naturalmente as mentalidades mais rudimentares e incultas a um nacionalismo incondicional, tendencialmente xenófobo e propenso a erigir a própria condição em ideologia. (JAGUARIBE, 1958, p. 35).

Vejamos que ao citar, no trecho acima, à "própria condição de classe", tratava-se de uma versão "primária” do nacionalismo, ausente da ideologia do desenvolvimento e composto da imaturidade das consciências dos setores sociais que a propagavam. Portanto, "incondicional", "inculta” e "rudimentar", são os opostos da "racionalidade" presente em um nacionalismo que contivesse a ideologia do desenvolvimento. Desta forma, as oposiçóes entre nacionalismo e cosmopolitismo preenchiam o panorama de um antagonismo pouco propositivo para o desenvolvimento.

O nacionalismo sem um planejamento nacional gerava contradiçóes. Partindo dessa premissa, Jaguaribe irá levantar algumas delas. Dissertaremos aqui sobre três: a econômica, a social e a política. No campo econômico, a contradição se baseava na tentativa de um desenvolvimento sem a utilização de capitais estrangeiros, porém, diante de uma realidade econômica carente de capitais "poupáveis ao consumo e aplicáveis em investimentos”(JAGUARIBE, 1958, p. 37). Tal carência agravaria o subdesenvolvimento no Brasil.

É exatamente contra o capital estrangeiro, todavia, que, de modo geral, se insurge o nacionalismo, nele vendo um fator de espoliação das riquezas naturais do 
país e um processo de agravamento de nossa dependência colonial. (JAGUARIBE, 1958, p. 38)

Ocorre uma mudança da postura de Hélio Jaguaribe sobre o papel do capital estrangeiro no desenvolvimento econômico do Brasil. Dois anos antes, na obra Para uma politica de desenvolvimento nacional, o autor analisava que a entrada de capitais estrangeiros não era um fator importante para o desenvolvimento do país. Segundo Jaguaribe, o capital estrangeiro já não seria mais "a salvação do país”, não representava um fator de desenvolvimento para o país, pois, tornou-se um ônus para a balança de pagamento. Para sustentar tal argumento, o autor apresenta o estudo do Banco do Brasil de 1953 que mostra que as entradas e saídas de capitais estrangeiros no Brasil durante o período de 1941-1952 apresentou um déficit de mais de Cr\$16,5 bilhões. Porém, uma opção de utilização do capital estrangeiro seria a possibilidade de empréstimos a prazo médio através de vendas financiadas de equipamentos. Segundo o autor, tal modelo se mostrara bem sucedido na Europa.

Sem explicitar sua mudança de opinião, o autor afirma que tal contradição poderia ser contornada se o Estado houvesse tomado medidas que incrementassem a capacidade nacional de investimento. Porém, na situação econômica que o país se encontrava, aumentar a capacidade nacional de investimento passaria por reduzir o consumo e elevar a produtividade, duas medidas que se tornaram inviáveis. A crítica também aponta na direção de um protecionismo nacionalista gerar uma baixa produtividade da indústria nacional devido à ausência de concorrência internacional, diminuindo a capacidade de renda nacional.

As contradiçốes da área social e política estão bem intrínsecas, sendo a política apresentada como uma síntese das contradiçóes econômicas e sociais. No campo social, refere-se à "[...] desproporção entre os benefícios auferidos ou desejados e a participação de cada qual na criação ou preservação de bens e valores sociais" (JAGUARIBE, 1958b, p. 40). Ou seja, a classe trabalhadora e a classe média não participam como potencialmente poderiam da produção nacional, porém, a consomem desproporcionalmente. Em relação à classe trabalhadora, Jaguaribe aponta que como não desenvolveram a consciência para lutar por uma sociedade que consolidasse a igualdade nas oportunidades de ascensão social (meritocracia) e a falta de igualdades sociais, a via "consistente e responsável" segundo o autor, acabaram investindo contra a espoliação de forma "inorgânica", através do populismo: "Deixando-se galvanizar por demagogos carismáticos [...]” (JAGUARIBE, 1958b, p. 41). Oresultado seria o aumento de "processos suicidas de consumo", gerando inflação e caos social. Por parte da classe média, o tema do "Estado cartorial” volta à tona: 
como o Estado teria se tornado um local da política de clientela e não uma esfera de prestação de serviços, a classe média, historicamente marginalizada do processo de produção, se ocupou de tais cargos de forma parasitária em sem desempenhar funçóes públicas em prol da sociedade. Desta forma, "a função do estado se limitou à arrecadação fiscal, para atender a uma despesa quase toda aplicada na remuneração do próprio funcionalismo" (JAGUARIBE, 1958b, p. 41).

A contradição, no campo político se encontrava, portanto, em almejar o desenvolvimento com o capital nacional e participação estatal sendo o próprio Estado uma estrutura cartorial, por conseguinte, obsoleta para o desenvolvimento e ao mesmo tempo que geradora de um déficit público. Portanto, aí reside o pecado do populismo e do clientelismo: o estrangulamento da condição econômicas do país, além de "acomodarem” ideologicamente o proletariado e a classe média, distanciando-os de uma ideologia do desenvolvimento.

A partir de uma visão hegeliana, Hélio Jaguaribe ressaltava em termos dialéticos que as contradições da atual fase brasileira e até as contradições dos modelos de organizaçóes sociais pelo mundo permitiriam as possibilidades de mudança de fases sócio-históricas das comunidades: “[...] todo processo histórico consiste na transformação de estruturas, em virtude e por meio de modificaçóes que conduzem a impasse as estruturas anteriores e forçam a criação de formas novas de organização e de trabalho.” (JAGUARIBE, 1958b, p.47). Após as condições dialéticas existirem, o autor depositaria em uma ação do campo da consciência, no sentido idealista, a capacidade de superar tais contradições. Logo, "a superação de tais incongruências depende, assim, de uma atuação cultural ou política que reajuste o movimento nacionalista aos imperativos do desenvolvimento, fim imediato que o suscita e orienta”. (JAGUARIBE, 1958b, p.58).

Essa dialética idealista irá orientar sua percepção histórica do desenvolvimento do Brasil e as condiçôes para interferir em seu curso. Neste sentido, mais do que reunir e saber direcionar elementos materiais, a priori o isebiano buscou compreender o "espírito" do movimento nacionalista. Isso o faz ter uma preocupação em compreender a ideia por trás de sua "força”. Não fugindo desta regra, portanto, o nacionalismo, a despeito de suas "versóes" primárias e esparsas, se constituiria para Jaguribe através de uma ideia que lhe orienta e lhe identifica como a versão correta e certeira dentre os nacionalismos contraditórios e impotentes. Portanto, o que daria sentido ao nacionalismo seria a sua ideologia.

Nesta direção, o nacionalismo é definido pelo cientista político enquanto um movimento provocado pelo desenvolvimento do país que ao mesmo 
tempo tem a finalidade de "acelerá-lo" e "racionalizá-lo", torna-se importante para o autor que tal movimento seja um "fim" e não um "meio". Em outras palavras, se a finalidade do nacionalismo é estabelecer

o desenvolvimento, não serão os meios empregados que definirão se é o ou não de fato nacionalista.

Compreende-se o nacionalismo como uma ideologia destinada a cumprir uma missão na fase histórica em que se encontrava o Brasil. $\mathrm{Na}$ medida em que o desenvolvimento econômico-social tivesse lugar, ele tenderia a desaparecer, A afirmação da Nação serviria como antítese da imposição da condição periférica e subdesenvolvida para o Brasil. Longe de uma noção essencialista ou estática, o nacionalismo defendido por Hélio Jaguaribe era historicamente transitório:

Paradoxalmente, o nacionalismo é antinativista e antifolclórico. Não significa isso o repúdio cultural às nossas tradiçốes nem a perda de sensibilidade para as contribuições da arte popular. Significa, apenas, que tais contribuições irão passando da vida para o museu, que nós as incorporamos como compreensão do passado e não como formas aprisionadoras de nosso devenir. (JAGUARIBE, 1958b, p. 55)

Para Hélio Jaguaribe, não se poderia confundir nacionalismo com nacional:"[...]é indispensável elucidar todos os equívocos tendentes a confundir com o nacionalismo o fato de serem nacionais os agentes ou recursos empregados para a obtenção de um fim qualquer”. (JAGUARIBE, 1958b, p. 52). À guisa de exemplo, o isebiano utiliza a questão do petróleo brasileiro. Para o autor, o que torna a política petrolífera nacionalista não é o fato de termos uma empresa nacional gerindo a extração e produção (a Petrobrás), porém, o fato do petróleo brasileiro estar sendo gerido da melhor forma possível em prol da economia do país.

A medida em que o apoio à Petrobras decorra mais da circunstância de ser uma empresa nacional ou um monopólio do Estado do que o mais eficiente instrumento para atender às nossas necessidade petrolíferas, marca a distinção entre o equivocado nacionalismo de meios e o nacionalismo de fins. (JAGUARIBE, 1958b, p. 53).

Jaguaribe imprime um caráter "sistemático” e "global” desta categoria, pois se o desenvolvimento é um fenômeno que deve atingir todas as dimensôes da sociedade, o nacionalismo não pode ser medidas esparsas, ou isoladas, característica própria do intitulado "nacionalismo de meio" que não pensa na totalidade. Para o isebiano, uma das funçốes do nacionalismo é integrar politicamente a comunidade. Desta forma, o autor retira esta categoria das vontades e posiçóes políticas individuais, sendo resultado de uma política 
planejada e "total", que abarcasse as soluçôes para as contradiçôes sócio-econômicas que vivessem todos os grupos sociais. Portanto, uma visão mecânica e formal do nacionalismo não o levará a depreender as condiçóes singulares do país para estabelecer um padrão próprio de desenvolvimento. Jaguaribe cita que na "perspectiva mecânico-formal" o modelo de desenvolvimento do Brasil seguiria padróes internacionais, ao invés de superar o atual modelo econômico irá, pelo contrário, aprofundar o modelo agro-exportador, através da orientação "mecânica" de aumentar a produção sem superar as contradiçôes macro do país: "O modelo econômico conveniente ao Brasil, portanto, não será o que, pura e simplesmente, nas atuais condiçôes do país e do mundo, lhe proporcione maior produtividade marginal". (JAGUARIBE, 1958 b, p. 61). Neste termo, o autor diferencia o crescimento econômico de desenvolvimento.

Sendo assim, é insuficiente para Jaguaribe que o desenvolvimento seja apenas uma ideologia de classe, nestas condiçốes prevalecerão os interesses de classe e não do próprio desenvolvimento, causando inevitavelmente uma aproximação entre os setores "dinâmicos" e "estáticos" de cada classe, e por outro lado, gerando uma contradição entre as classes sociais: "[...] e a solidariedade de classe alia o capitalista produtivo aos improdutivos; as garantias de emprego [...] a remuneração [...] passam a constituir objetivo primeiro e básico, em lugar de ser decorrência do desenvolvimento" (JAGUARIBE, 1958 b, p. 64). Desta forma, para se considerar nacionalista, a ideologia do desenvolvimento deve ser também autêntica, pois o nacionalismo teria uma premissa agregadora dos grupos sociais de uma nação.

As direções que esta obra segue têm um sentido básico de dirimir as "polêmicas" contemporâneas ao autor que o mesmo julgava inócuas para o desenvolvimento. Um dos principais embates era entre os que defendiam a gestão estatal e os que defendiam a sua privatização.

[...] de um lado, quase toda a grande imprensa, a maioria dos sindicatos patronais e diversos congressistas, denunciando a imoderada intervenção do Estado na órbita econômica [...] de outro lado, a maioria dos sindicatos de empregados e muitos parlamentares, defendendo a intervenção econômica do Estado, sustentam a necessidade de expandir a gestấo pública a todos os setores estratégicos [...]. (JAGUARIBE, 1958b, p. 66).

Apesar da polêmica, a tendência do governo JK na época era expandir a desestatização de estradas de ferros, estaleiros e portos. Jaguaribe aponta o caráter "deslocado" desta polêmica diante dos fatos concretos que caminhavam apenas um uma direção. Porém, o que de fato tonificava o debate era a crescente campanha em torno da participação de capital estrangeiro no setor petrolífero. Cabe lembrar que o Estado brasileiro tinha o monopólio 
do petróleo em solo nacional desde a promulgação da lei que criava a Petrobrás em outubro de 1953. Importante ressaltarmos que a análise realizada por Hélio Jaguaribe foca na dimensão nacional da iniciativa privada e não no capital estrangeiro em si. "[...] sendo o capital estrangeiro matéria distinta da forma pela qual se encare a iniciativa privada."(JAGUARIBE, 1958b, p. 68).

$\mathrm{O}$ autor amplia sua análise para as raízes sociológicas da relação entre o indivíduo e o Estado. A conclusão que chega é que se trata de um ponto que não configura controvérsia para a ciência política, a verdadeira questão tratava-se do debate sobre a gestão econômica, ou seja, se a privacidade incluída em todos os regimes deveria abarcar ou não o direito à propriedade e gestão pública. Nestes termos, o isebiano leva o rumo da análise para um comparativo entre capitalismo e socialismo. Jaguaribe afirma que a "marcha histórica" dos dois regimes se encaminha para uma convergência, pois ambos se modificaram e se afastaram de suas premissas clássicas. Ao ponto de o autor afirmar que "não há mais países capitalistas e socialistas" a rigor (JAGUARIBE, 1958, p. 87). Nessa perspectiva, havia um socialismo ao preconizar que as atividades sociais são funções sociais e um capitalismo na preservação da acumulação capitalista em prol do desenvolvimento.

\section{CLASSES SOCIAIS, IDEOLOGIA E DEMOCRACIA}

Jaguaribe não nega a existência de conflitos sociais no Brasil. Contudo, ele não os enxerga da mesma maneira que seus contemporâneos ligados ao comunismo ou ao trabalhismo, se estes davam protagonismo aos trabalhadores no processo de desenvolvimento, Jaguaribe desenvolve uma interpretação histórica do Brasil que resulta na defesa do protagonismo da burguesia como agente modernizador. Para o autor, a luta fundamental não seria entre as classes, mas entre os setores internos delas, que poderiam ser dinâmicos ou estáticos. Logo, o que haveria de ser superado não era a composição social, mas a estrutura faseológica do Brasil. Nesta modalidade de conflito, a tensão se daria entre aqueles acomodados no seu momento histórico e os obsoletos.:

Em outros dois livros do autor, publicados durante sua atuação no ISEB, aparece de forma mais clara alguns pontos que marcam a relação que ele estabelece entre interpretação e compreensão do processo histórico e a formação de projetos políticos para o país a partir de uma ideologia nacionalista. São eles: O problema do desenvolvimento econômico e a burguesia nacional (JAGUARIBE, 1958c) e Condiçóes Institucionais do desenvolvimento (JAGUARIBE, 1958a).

Para Jaguaribe (1958a) (1958c), o Brasil teria passado por três fases na sua história, cada qual correspondente a uma determinada estrutura-tipo A 
primeira teria permanecido desde o descobrimento do Brasil até século XIX. Seu perecimento teria começado por volta de 1850 , com a progressiva substituição de mão de obra escrava pela assalariada. Para oautor, a condição colonial de um país seria definida por duas principais características, sendo elas a heteronomia, na qual: “...o processo econômico é provocado por fatores externos à própria comunidade, quer dizer, é determinado pelas suas relaçóes de intercâmbio.” (JAGUARIBE, 1958b, p. 14) e a exogenia, que se definiria pelo acúmulo de renda ocorrer apenas na metrópole, privando a colônia de seus benefícios.

O trabalho escravo, característico da estrutura-tipo colonial, não permitiria o processo interno de acumulação de renda, pois não haveria salário e logo não se faria possível sua troca por consumo. "Não havendo pagamento de salários, a sociedade cresce por justaposição de riquezas. A uma fazenda de café se acrescenta outra fazenda de café, mas não há circuito de investimento, relação de investimento, produto e poupança.” (JAGUARIBE, 1958 a p. 15). A única acumulação que existira em território nacional seria a de riqueza, uma vez que a de renda se faria no exterior " [...] no processo de venda de escravos, de compra e de revenda do produto primário importado pela comunidade colonial” (JAGUARIBE, 1958a, p. 15)

Segundo o autor, a transição de uma dessas fases históricas do processo econômico brasileiro para outra necessitaria a conjugação de um fator externo com um interno. Assim, amudança da estrutura-tipo colonial para a semicolonial seria resultado da extinção do tráfico e a consequente alteração do regime de produção para o de mão de obra assalariada.

A segunda estrutura-tipo, a semicolonial, teria durado de 1850 até a crise do café nos anos 1920. A crise de 1929 seria responsável por agravá-la. Nela "...o Brasil se depara com a incapacidade de continuar financiando, com o produto da sua exportação cafeeira, todas as necessidades do seu consumo.” (JAGUARIBE, 1958a, p. 16), Nesta estrutura-tipo persistiria a heteronomia, mas a exogenia tenderia gradualmente a desaparecer, pois uma vezimplementada a mão de obra assalariada, surgiria o mercado interno consumidor.

A partir dos anos 1930, o Brasil estaria entrando em uma terceira fase de transformação. Nas fases colonial e semicolonial as classes dirigentes produziam e vendiam sobretudo café, pois era o produto que apresentava maior taxa de rendimento por causa das condiçóes naturais que favoreciam sua produtividade. Contudo, a crise deste modelo teria forçado o país a investir no mercado interno. O Fator externo que teria possibilitado o avanço para essa etapa foi a crise cambial, enquanto o interno foi a formação de um mercado voltado para o país. 
Uma vez que o principal produto de exportação brasileiro era o café, ele não aumentaria seu consumo externo de acordo com o aumento per-capita das naçóes compradoras. O único fator que influiria no aumento de sua compra seria o crescimento vegetativo da população dos países, inferior às necessidades de exportação do Brasil. Ao mesmo tempo, a população brasileira estaria crescendo, assim como suas necessidades de consumo. As divisas adquiridas pela venda de café não seriam suficientes para suprir esta demanda. Esse problema teria se agravado ainda mais com a crise de 1929, obrigando o Brasil a produzir internamente os produtos acabados que não conseguia mais adquirir no exterior. Adicionou-se a isso a crise cambial, que criou obstáculos para a entrada de produtos estrangeiros concorrentes. A solução foi a industrialização do país, pela diversificação da lavoura, voltada a partir daí também para o mercado interno.

Para Hélio Jaguaribe, o Brasil estaria nos anos 1950 em uma fase na qual a sua estrutura-tipo subdesenvolvida se encontraria em momento de transição entre a situação colonial e a situação autônoma. O país teria capacidade de desenvolver-se e superar o momento de transição, contudo, haveria obstáculos. Os principais problemas seriam as características subdesenvolvidas do Brasil: baixa renda per-capita em relação aos outros países, diferenciação do consumo entre as classes e a predominância da produção primária sob a produção elaborada. Em suma, para seu país se tornar desenvolvido e autônomo, o autor acreditava que ele precisaria primeiro que o setor agrário-exportador deixasse de ser maior e mais importante do que o setor industrial.

O fato de o Brasil não ter à época uma indústria desenvolvida manteria o país atrasado. Sua situação enquanto semicolonial se daria justamente por manter características arcaicas que o impediriam de ser autônomo. Para Jaguaribe:

A situação colonial é uma situação que independe das relaçốes políticas; ela é determinada, sobretudo, pela situação econômica, social e cultural do país dado, em relação a outros que, ainda que sem a inculcação política expressa da condição de metrópole, atuam para com este país tal como se o fossem. (JAGUARIBE, 1958c, p. 20).

Jaguaribe parece entender especificamente no trecho acima a política como administração e domínio direto do território. Portanto, ele define a situação colonial como, estar-se submetido a uma metrópole por imposição de uma lógica econômica e cultural, independente de se pertencer oficialmente ao território dominador. O Brasil tinha como principal consumidor e exportador os EUA, sendo mais de $50 \%$ do comércio exterior nacional feito com esse país. Para Jaguaribe isto "[...] mostra que os Estados Unidos da América, independentemente de vínculos políticos, funcionam como um 
país semi-metropolitano em relação ao Brasil.” (JAGUARIBE, 1958c, p. 22). Portanto, os EUA seriam a semi-metrópole da semi colônia Brasil.

Enquanto país semicolonial, o Brasil já teria começado a operar em função do seu mercado interno e possuiria processos internos de capitalização que começaram a permitir oseu crescimento interno, com investimentos próprios. Ele se encontraria em uma etapa na qual teria tendência progressiva de diminuição de dependência do comércio exterior, com crescimento da produção interna. Entretanto, a etapa em que o país se encontraria não o privaria de ter problemas a resolver, sendo os principais a crise no comércio exterior e a diferença entre oferta de bens e serviços (energia elétrica, combustíveis, serviços de base e transportes).

De 1947 em diante o equilíbrio entre importaçóes e exportaçóes teria começado a se romper. A crise aberta daí em diante seria a segunda etapa da crise cambial: "O país não tem mais capacidade de financiar as importações de equipamentos de que necessita para produzir os produtos acabados, de que por sua vez necessita para atender ao seu mercado interno.” (JAGUARIBE, 1958c, p. 36) Enquanto o Brasil continuasse a exportar majoritariamente produtos primários não haveria maneira de aumentar divisas para reverter este quadro.

A infraestrutura nacional seria inadequada para esta fase. A estrutura do país não teria se modificado o suficiente desde os anos 1930, fato que poderia ser comprovado pela relação entre investimento total e rendimento serem muito baixa entre setor de transportes e o de produção de serviços públi$\cos$ (apenas 4.4\% em dados trazidos pelo próprio). Isto tornaria esses setores pouco atrativos para o investimento do capital privado. O problema poderia ser superado se a industrialização brasileira se acirrasse ainda mais. $\mathrm{Na}$ etapa em que o Brasil se encontraria, a maneira de vencer os gargalos do desenvolvimento, seria que ele passasse "...a produzir internamente os equipamentos que até agora vínhamos importando.” (JAGUARIBE, 1958c, p. 42). Nesta etapa de transição, seria preciso não só produzir nacionalmente as próprias fábricas para atender o mercado interno, mas também seus equipamentos. Isso permitiria o equilíbrio da balança comercial brasileira e o consequente avanço do desenvolvimento.

Segundo a análise de $O$ problema do desenvolvimento econômico e a burguesia nacional (JAGUARIBE, 1958a), o processo de desenvolvimento que o Brasil passou desde 1930 teria sido responsável por gerar uma mudança na sua estrutura social. De uma classe dirigente de latifundiários com relação predatória e especulativa com a terra, passou-se a uma burguesia diversificada, com setores industriais e preocupados com o mercado interno. Formou-se também o proletariado e uma classe média diversificada. Esta 
última, teria deixado de se empregar apenas no funcionalismo público para ocupar também cargos técnicos e administrativos nos novos empreendimentos que surgiram.

No entanto, este processo econômico e social não teria evolução política correspondente. A estrutura do Estado brasileiro seria basicamente a mesma de antes de 1930, o que dele faria um "Estado Cartorial” (JAGUARIBE, 1958a, p. 51). O autor define tal conceito da seguinte maneira:

Estado Cartorial é o Estado que resulta de uma situação em que o jogo do poder se faz em termo de política de clientela. A política de clientela, por sua vez, consiste no processo pelo qual se constitui o poder, uma comunidade em que existe um grupo detentor dos meios de produção rural, que são os latifundiários, apoiado por um grupo mercantil dos centros urbanos e em torno dos quais gira necessariamente toda a possibilidade de emprego, toda a possibilidade de concessão de favores, de sorte que as clientelas se organizam em forma piramidal, através de contratos tácitos ou relaçôes semelhantes, para assegurar uma composição política correspondente a essa mesma composição econômica. (JAGUARIBE, 1958a, p. 51)

Nesta fase do Brasil, haveria um desarranjo entre o econômico-social e a estrutura do Estado-nacional. Este seria responsável por conservar uma contradição: a classe industrial teria a propensão de assumir o comando do processo econômico e social, mas o Estado brasileiro era de tipo agrário, dominado por coronéis que conservavam um poder excessivo.

A manutenção do Estado Cartorial se deveria, em partes, ao fato de que as classes no Brasil seriam vítimas de uma confusão ideológica geral. O Proletariado seria vítima de equívocos que o levariam ao assistencialismo e o culto de um líder carismático. No entanto, o que ele necessitaria de fato seria a expansão do desenvolvimento econômico, pois é a baixa produtividade que não permite a remuneração adequada da classe.

Já a Classe média, era seduzida por movimentos moralistas como o lacerdismo. Para Jaguaribe, este tipo de norma de conduta cultivada pela classe média seria próprio do meio rural, devendo tornar-se ultrapassado na fase em que o Brasil estaria. $\mathrm{O}$ autor compreendia que a classe média não queria perder privilégios e nem símbolos de diferenciação social que permitissem seu contraste em relação aos proletários. Em suas palavras:

E cultiva preconceitos anti-industriais e anti-proletários, parcialmente motivados pelo fato de que na evolução de uma sociedade agro-pastoril para uma sociedade industrial, tendem a desaparecer as pequenas sutilezas da hierarquia social, em torno do qual tanto se aferra a classe média. (JAGUARIBE, 1958a, p. 54) 
O que de fato a classe média necessitaria é do desenvolvimento. Com o incremento de parques industriais ela seria empregada em cargos técnicos e administrativos, o que permitiria, inclusive, o acesso de mais pessoas ao lugar da pequena burguesia. Isso também retiraria a classe média do lugar marginal que teria em seu país. Com a industrialização, a classe média poderia se inserir de fato no processo produtivo, enquanto em uma sociedade agrária permaneceria sem lugar.

O problema da burguesia - classe vista como protagonista no processo estaria no fato de que seu setor mercantil continuaria na liderança. Quando o interesse da burguesia industrial fosse atendido, o de todas as demais classes também seriam. Hélio Jaguaribe era leitor de Joseph Schumpeter (1961). Deste autor, ele retirou sua compreensão de que oempresário capitalista é o ator responsável por trazer a inovação:

A ordem capitalista, da maneira como está materializada na instituição da empresa privada, prende eficientemente o capitalista ao seu trabalho" [...] O mesmo sistema que, em uma determinada época, condiciona os indivíduos e as famílias que formam a classe burguesa, seleciona também, ipso facto, os indivíduos e famílias que ascenderão nesta classe ou dela serão excluídos. Esta combinação de função estimuladora com função selecionadora não é absolutamente coisa simples. [...] "O homem que ascende, em primeiro lugar, à classe dos homens de negócio e, depois, dentro dela se mostra indivíduo capaz, ascenderá com toda a probabilidade até onde o puder levar sua capacidade, simplesmente porque, neste esquema, ascender a uma posição e nela atuar bem é, ou sempre foi, de maneira geral a mesma coisa. Este fato, tão frequentemente obscurecido pela tentativa autoterapêutica dos fracassados para negá-lo, é muito mais importante para a apreciação da sociedade capitalista e da civilização que ela cria do que tudo que se possa recolher da teoria pura do sistema capitalista. (SCHUMPETER, 1961, p. 95)

Tanto Schumpeter quanto Jaguaribe compreendem uma divisão social entre classes dirigentes e dirigidas na qual cabe à primeira empreender para levar o desenvolvimento para as demais. Em ambos os autores quem cumpre este papel é o empresário capitalista, durante o processo de desenvolvimento, a relação entre as classes sociais precisaria ser de cooperação. $\mathrm{O}$ autor austríaco apresenta esta conclusão a partir de crítica que faz ao conceito de luta de classes de Karl Marx:

Para qualquer mente não deformada pelo hábito de orar pelo rosário marxista, deve ser evidente que a relação entre as classes, em tempos normais, é, principalmente, de cooperação e que qualquer teoria contrária deve basear-se, em grande parte, para verificação, em casos patológicos. Na vida social, antagonismo e colaboração apresentam-se juntos e são, de fato, inseparáveis, exceto em casos muito raros. (SCHUMPETER, 1961, p. 29) 
Jaguaribe recepcionou estas ideias para o Brasil,adequando-nas à situação nacional. Para ele, haveria uma "Missão da Industria nacional" (JAGUARIBE, 1958c, p. 55). Partindo do conceito de Ideologia tal como pensado por Karl Mannheim, Jaguaribe concluiu que a burguesia apresentaria as linhas de representatividade e de autenticidade do mesmo:

Pode-se chamar como representativa uma ideologia que efetivamente corresponde aos interesses situacionais do grupo de que ela é a expressão; pode-se chamar de autêntica a ideologia que realmente corresponde às necessidades da comunidade no momento dado. Ora, neste momento, aquilo de que realmente o país tem necessidade, que é a promoção do seu desenvolvimento econômico em termos de mobilização ótima dos fatores disponíveis no país, em função deste, é exatamente o que corresponde ao interesse da burguesia nacional. (JAGUARIBE, 1958a, p. 55 e 56)

$\mathrm{O}$ interesse da burguesia industrial representaria, portanto, o interesse de todas as classes: o desenvolvimento. Caberia a esta burguesia cumprir seu papel histórico de promovê-lo. Isso deveria ser feito a partir da formulação de uma Ideologia não só representativa da burguesia, mas autêntica do Brasil, uma vez que estaria de em harmonia com o interesse de todas as classes sociais. Angélica Lovatto (2010) elucida melhor este ponto:

No decorrer da análise do pensamento de Hélio Jaguaribe percebe-se claramente a reafirmação de que a representatividade e a autenticidade ideológica estavam presentes na burguesia industrial brasileira. Isso porque ela representaria o dinamismo econômico daquele momento, ou seja, a base moderna sobre a qual deveria se processar a reforma do Estado. Esta classe congregava todos os interesses situacionais e seria, por isso mesmo, a mais autêntica para conduzir, enquanto força dirigente, o desenvolvimento nacional. (LOVATTO, 2010, p. 104)

Como consequência de sua interpretação da História do Brasil e de suas leituras de Schumpeter e Mannheim, Hélio Jaguaribe acreditava que o desenvolvimento econômico, social, político e cultural do país seria alcançado via um processo de industrialização liderado pela burguesia. $\mathrm{O}$ resultado disto seria a ruptura do páis com todos os resquícios coloniais que o prenderiam, tornando-se autônomo em todos os campos. Recepcionando a obra de Ortega y Gasset (s.d.), Jaguaribe passou a enxergar não só o indivíduo, mas a própria nação como algo que se faz dentro de sua própria história.

Assim como propõe o filósofo espanhol, é tomando consciência das circunstâncias que a condicionam historicamente que é possível dar sentido para a vida. Mas, para obrasileiro, trata-se da vida do país e como o seu processo histórico o condiciona em determinado sentido no qual ele mesmo deve ser agente de sua mudança. A razão histórica passa a ter com Hélio Jaguaribe enquadramento nacional, fornecendo junto com a sociologia do 
conhecimento de Karl Mannheim aparato teórico-metodológico que pretendeu compreender o passado histórico do Brasil para lhe formular um projeto político adequado para o seu desenvolvimento e, consequentemente, sua emancipação.

Tal como o próprio nome de uma de seus livros propóe, o autor entende que para atingir o desenvolvimento seria preciso antes garantir certas condições institucionais para o mesmo. Estas ideias são fruto de recepção de outro trabalho de Karl Mannheim, desta vez Liberdade, poder e planificação democrática (MANNHEIM, 1972). O sociólogo húngaro pretendeu propor nesta obra um modelo de planificação que fosse o mesmo tempo democrático. Sua intenção era superar os excessos cometidos tanto pelo Capitalismo dos Estados Unidos da América e quanto pelo comunismo da União das República Socialistas Soviéticas. Para tal, Mannheim julgava ser importante não só modificar as estruturas econômicas de uma sociedade, mas também as políticas e culturais. Segundo ele:

Sem menosprezar a significação da estrutura econômica, salientaremos que, sem as modificaçóes correspondentes no plano político e cultural não há reformas satisfatórias. Cada vez mais se reconhece que a verdadeira planificação consiste na coordenação das instituiçóes, da educação, dos valores e da psicologia. Só quem puder ver as importantes ramificaçóes de cada passo isolado, poderá atuar com a responsabilidade exigida pela complexidade da época moderna. Nestas circunstâncias, um livro sobre a essência da planificação democrática deve tomar como tema a vida social em sua totalidade: novas instituições, homens novos, valores novos. (MANNHEIM, 1972, p. 17-18)

Partindo da inspiração mannheimiana de compreender e resolver os problemas de uma comunidade a partir da compreensão de todos os seus componentes, Hélio Jaguaribe propôs soluçôes para o caso brasileiro. $\mathrm{O}$ autor formulou então seu conceito de "institucional" com dois sentidos. No Sentido amplo, ele seria o próprio processo social. Nesta definição, seria institucional tudo que fosse construção social humana. Já no sentido restrito, ele seria:

Em sentido estrito, porém, o institucional se distingue do processo social global como o ato pelo qual, no processo global, a comunidade erige determinados valores como fins, determinadas normas como processo, e assim organiza entidades operativas para a consecução dos seus fins. (JAGUARIBE, 1958b, p. 39)

Haveria comprovação histórica da influência de ambos sentidos do conceito de institucional nos processos de desenvolvimento. $\mathrm{O}$ amplo se verificaria pela relação entre oprotestantismo calvinista e a formação do capitalismo. Já no sentido de instituiçóes como normas que ordenam o processo social, a principal seria o Estado moderno, tanto como agente quanto como norma. 
Para o autor, a diferença entre os dois conceitos de Instituição derivaria politicamente em duas concepções distintas do processo de desenvolvimento. Elas, por sua vez, seriam representadas por ideologias políticas que buscariam lhes dar sentido teórico. O conceito de Institucional no sentido amplo seria representado pelo liberalismo, concebendo então o desenvolvimento como decorrente da livre espontaneidade do meio social. Já o conceito estrito entenderia o desenvolvimento como fruto de ação diretora e configuradora do processo. As teorias que buscariam dar sentido a essa forma de compreender o processo de desenvolvimento seriam representadas pelas concepções de Estado interventor e diretor.

Para resolver este conflito entre opostos, Hélio Jaguaribe aplicou em Condiçôes Institucionais do desenvolvimento (JAGUARIBE, 1958a) o mesmo procedimento dialético que depois organizou $O$ nacionalismo na atualidade brasileira (JAGUARIBE, 1958b) como um todo. Apresentando ideias contrárias, ele as organizou enquanto tese e antítese e procurou superá-las a partir de uma síntese. Esta, por sua vez, incorporaria características das duas ao mesmo tempo em que avançaria para além delas. Assim como Mannheim (1972), Jaguaribe se esforçou nesse procedimento por oferecer uma terceira via para a resolução dos conflitos que marcavam o seu tempo, dando a esta o sentido de um caminhar histórico dialético. Nas palavras do autor:

Vale a pena, porém, observar que, historicamente, a controvérsia tende a ser superada, quer no nível teórico, quer no nível prático. Verificamos que diminui cada vez mais o número dos autores que propendem a defender uma posição liberal estrita, e paralelamente os que tendem a defender o dirigismo total." (JAGUARIBE, 1958a, p. 40)

A crítica de Hélio Jaguaribe ao liberalismo tem por base a percepção de tal corrente do pensamento como teoria abstrata, que pressuporia um homo economicus racional inexistente. Todavia, sua antítese - o dirigismo - também seria problemática, pois visaria esgotar o real pelo conceito (JAGUARIBE, 1958a, p. 41), impondo de cima para baixo políticas concebidas no plano intelectual. A solução do autor foi conciliar estes contrários, dando à síntese produzida o sentido de um caminhar histórico para determinada direção. Para Jaguaribe, seria o planejamento democrático que resolveria tal conflito, a partir da criação de uma teoria que correspondesse às exigências da história. Eis, para o autor, a principal condição institucional para o desenvolvimento:

Essa propensão a realizar, tanto na prática como na teoria, uma conciliação entre os princípios da espontaneidade e do dirigismo, quebrando o radicalismo anterior, representa a tendência, em nosso tempo, a conceber as condiçóes institucionais do desenvolvimento, como algo que deve ser organizado na forma de um planejamento democrático. Planejamento que não só induza os cidadãos a 
se autodeterminarem - reservando-lhes certa área de privaticidade no âmbito da qual funcionem, com a espontaneidade, os móveis psicológicos e sociais correntes -, mas também organize condiçóes e estímulos diretos e indiretos que levem ao desenvolvimento a se processar de acordo com a expectativa contida no plano. (JAGUARIBE, 1958a, p. 42)

Consequência da análise feita pelo autor das estruturas-tipo do Brasil, o país estaria em uma fase histórica na qual o desenvolvimento começaria a ter condiçóes materiais para ocorrer. Os principais fatores endógenos que permitiriam isso seriam o aumento do mercado, determinado pelo crescimento da população, e o enriquecimento per capita, responsável por expandir para o interior hábitos de consumo que antes estavam só em regiôes litorâneas. Já os principais fatores exógenos seriam as crises cambiais dos anos 1920 e dos anos 1940. A primeira teria forçado o abandono do antigo sistema produtivo agrário-exportador e a segunda teria forçado a produção de equipamentos para compensar as carências cambiais.

Contudo, todo o esforço econômico teria sido em vão se não ocorresse também a superação dos "pontos de estrangulamento" (JAGUARIBE, 1958a), a serem ultrapassados por marcos institucionais. Estes existiriam em quatro níveis: econômico, social, cultural e político. No nível econômico o ponto de estrangulamento seria o fato de que formação de poupança e de investimento não coincidiria com as necessidades da população, gerando desequilíbrio na oferta de serviços de bens e de infraestrutura. Para Jaguaribe este problema não é tão grave, pois tenderia a ser superado no longo prazo. Inclusive, o uso de capital estrangeiro não seria dispensável para tal.

No nível social, os pontos de estrangulamento seriam a tendência de manutenção de privilégios de classe e parasitismo social. Eles impediriam que a sociedade ganhasse sentido democratizante. Todas as classes (proletários, classe média e burgueses) sofreriam com o parasitismo. Proletários seriam reféns de um sistema político-jurídico que não era moderno e a classe média ficaria ociosa. Por sua vez, a burguesia continuaria com empreendimentos menos produtivos, exemplificado pelo autor com o açúcar do Nordeste, que só seria capaz de competir com o do Sul por ser subsidiado. Hélio Jaguaribe defende a democratização como necessária, sua ausência seria fator de estrangulamento social. O planejamento que deve ser feito na fase histórica que se abria para o Brasil deveria ser democrático, como o de Mannheim (1972). Apenas democratizando o país seria possível modernizá-lo:

No plano das nossas relações sociais, esses fenômenos de estrangulamento se apresentam em termos de permanência, além do período em que historicamente ainda eram compreensíveis, dos privilégios de classe, que tendem a enquistar-se em determinados sistemas de resistência e dificultam a horizontalização da de- 
mocracia brasileira, suscitando, ademais, um fenômeno extremamente grave, que é o parasitismo social. (JAGUARIBE, 1958a, p. 17)

Existiriam dois estrangulamentos da cultura, ambos criticados pelo autor por seus excessos. Como lhe é característico, Jaguaribe almejava sua síntese. Estes pontos seriam a alienação colonial, responsável por produzir a implantação mecânica de lógicas exógenas, e o nativismo primário, que engessaria a cultura brasileira. O problema do último é que as características brasileiras mantidas pelo subdesenvolvimento são postas como inalteráveis. $\mathrm{O}$ alvo da crítica de Jaguaribe é a coexistência de duas mentalidades. Uma, de origem colonial perceberia tudo no Brasil como inferior ao que vem de fora. Outra, teria como pressuposto um conceito de nação e de cultura essencialistas e conservadores, sem pensá-los como inseridos em uma dinâmica histórica que os modificaria. Jaguaribe compreende que se afirmar como brasileiro é afirmar sua Nação como uma igual às demais, entendendo que, como sua História é diferente e sua estrutura-tipo única, as ideias que teriam determinado sentido em outros países, no Brasil seriam recepcionadas e dialogariam com a realidade tal como aqui ela se encontra. Os problemas de uma mentalidade alienada são expostos pelo autor na passagem abaixo:

A alienação leva o brasileiro a pensar como se fosse inglês, francês, ou americano, esquecido de que, se os instrumentos teóricos da cultura ocidental se caracterizam por sua 'transferibilidade', nunca é transferível a perspectiva, sempre própria de cada pessoa, de cada povo e de cada momento, e que, portanto, toda transplantação cultural que consigo acarrete a transferência de perspectiva, falseia a possibilidade de utilização dessa cultura, desse instrumento teórico, por contrabandear uma perspectiva que a torna inautêntica. (JAGUARIBE, 1958a, p. 45)

Para que as condições institucionais do desenvolvimento fossem atingidas seria necessária a agência de setores esclarecidos, capazes de instruir a burguesia sobre o processo que o Brasil estaria passando, tornando-a ciente de seu papel histórico de encabeçar o desenvolvimento. Mannheim (1972) nomeia este tipo de elite de Intelligentsia. Hélio Jaguaribe concorda com o sociólogo húngaro que sem este setor e sem ideologia não há condiçóes institucionais para o desenvolvimento:

Para poder instaurar as condições institucionais que tornarão possível a aplicação dos planos e farão do planejamento a função precípua do Estado, é indispensável a mobilização ideológica, em virtude da qual os diversos setores que compõem a sociedade brasileira conciliem o seu próprio interesse com os objetivos do plano. (JAGUARIBE, 1958a, p. 49) 
A partir de recepção da obra Ideologia e Utopia de Mannheim (1987), Jaguaribe compreende ideologia como "[...] uma racionalização de expectativas de organização da sociedade, decorrente da posição situacional dos membros dessa sociedade." (JAGUARIBE, 1958a, p. 49). Na fase em que o Brasil se encontraria, haveria correspondência dos interesses das classes com as condiçóes institucionais necessária para o desenvolvimento, ambos se beneficiariam do aumento de produtividade. Portanto, uma ideologia voltada a instruir a burguesia industrial seria mais representativa e a mais autêntica para o Brasil, uma vez que teria conexão lógica e factual entre suas formulações e a classe que representa as exigências de sua comunidade na fase em que se encontraria o país.

A educação ideológica faria a burguesia brasileira ter consciência de seu papel no desenvolvimento, se convertendo de burguesia latifundiária e agrário-exportadora para “[...] burguesia nacional e progressista.” (JAGUARIBE, 1958a, p. 52). Do mesmo modo, o problema de reorganizar o Estado para deixar de ser cartorial e parasitário, tornando-se funcional, seria “...um problema de educação e organização ideológica.” (JAGUARIBE, 1958a, p. 53). Tal como propóe Angélica Lovatto:

Construir uma ideologia desenvolvimentista significava, para Jaguaribe, construir uma ideologia nacionalista. Esta construção implicava na "criação de uma sociedade desenvolvimentista e o desencadeamento de condiçóes" que propiciassem "a superação do subdesenvolvimento econômico" e estivessem "essencialmente vinculados à ideia de planejamento. (LOVATTO, 2010, p. 109)
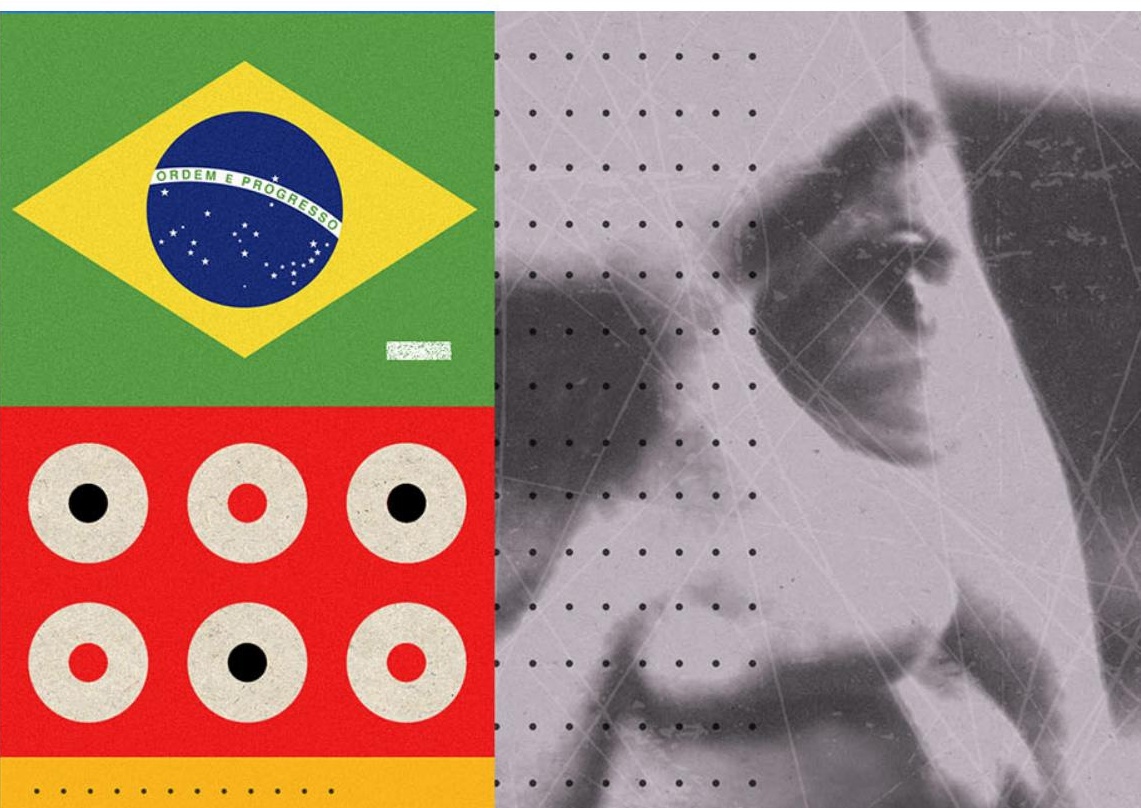
Os outros pontos de estrangulamento verificados estariam no nível político, representados pelo Estado Cartorial e pela política de clientela. As duas estruturas existiriam em simbiose, uma alimentando a outra e impedindo igualmente que se tenha um Estado hábil, independente de classes improdutivas. Também a partir da Ideologia que Hélio Jaguaribe tentou propor uma superação dos pontos de estrangulamento políticos, afirmando que as mudanças estruturais precisam ser também democratizantes. Seria do interior de um regime democrático ajustado aos valores culturais brasileiros que sairia a fórmula que reajustaria o Estado às forças dinâmicas capazes de conduzir o processo social.

O autor percebe a ascensão de uma nova forma de fazer política após a complexificação da sociedade e seu crescimento vegetativo. Estas teriam impedido que a relação entre político e eleitor fossem meramente clientelistas, fazendo emergir a "política ideológica" (JAGUARIBE, 1958a, p. 30). Hélio Jaguaribe a define como aquela que se oporia à política de clientela e “[...] em lugar de estabelecer uma barganha interindividual ou intergrupal do favor pelo voto, estabelece uma relação de orientação entre os interesses situacionais de determinado grupo ou de determinada classe e as formulações que convém a esse grupo e a essa classe. " (JAGUARIBE, 1958a, p. 30). O que o autor pretendia com essa nova forma de fazer política era aplicar os critérios de representatividade e de autenticidade da Ideologia às eleições. Determinada classe, que se beneficiaria de determinado programa, votaria em um candidato que o representasse. No entendimento de Angélica Lovatto (2010), a questão política seria o problema fundamental a ser resolvido ea política ideológica seu método:

\begin{abstract}
Registre-se que, na hierarquia dos problemas, a questão política aparece sempre em primeiro lugar, ou seja, como a condição essencial para o desencadeamento dos outros fatores. Aqui se encontra uma das determinantes fundamentais levantadas por Jaguaribe para o encadeamento das soluçóes nacionais: a necessidade da manutenção do que chama de política ideológica, em torno da qual a sociedade se mobilizaria como substituta corretiva da política de clientela. (LOVATTO, 2010, p. 103)
\end{abstract}

\title{
CONSIDERAÇÕES FINAIS
}

Tal como já foi exposto aqui anteriormente, $O$ Nacionalismo na atualidade brasileira (JAGUARIBE, 1958b) é organizado inteiramente pela exposição do conflito de teses contrárias para tentar propor a superação destas. Em algumas obras anteriores de seu período de atuação no ISEB, Hélio Jaguaribe já demonstrava não ser totalmente contrário à entrada de capital externo para 
auxiliar no desenvolvimento nacional. Em resposta a Jorge Martins Rodrigues na sessão de debates de $O$ problema do desenvolvimento e a burguesia nacional (JAGUARIBE, 1958c) o autor já defendia que a melhor forma de investimento estrangeiro para o Brasil seria a de empréstimos externos, pois eles permitiriam a permanência dos lucros no país e sua consequente acumulação de renda. O motivo principal apresentado pelo autor é que, na fase em que o Brasil se encontrava, ele não teria poupança suficiente para fazer sozinho o seu processo de desenvolvimento.

Ao analisar a questão do Petróleo, Jaguaribe apresenta em $O$ Nacionalismo na atualidade brasileira (JAGUARIBE, 1958b) que:

[...]o que torna nacionalista a atual política do petróleo não é o fato de a Petrobrás ser uma empresa do Estado brasileiro, dirigida por brasileiros natos, etc.. Em tese, a política nacionalista do petróleo poderia ser realizada pela Standard, ou qualquer outra empresa, desde que, concretamente, na situação do país, essa fosse a forma mais eficaz de explorar o petróleo brasileiro e proporcionar à economia nacional o pleno uso e controle de tal matéria-prima. (JAGUARIBE, 1958b, p. 52).

Segundo Angélica Lovatto (2010), o que o autor pretendia com tal assertiva era mediar as posiçôes contrárias, defendendo que o uso da capital estrangeiro não era intrinsicamente ruim, desde que seus efeitos espoliativos fossem controlados. Se era erro dos cosmopolitas subestimar a capacidade de desenvolvimento autônomo do país, os nacionalista se equivocavam ao exagerá-la. Uma vez que Hélio Jaguaribe defendia um nacionalismo pragmático, caberia:

[...] utilizar os meios que fossem necessários, independentemente da origem de seus agentes - mesmo os estrangeiros - para alcançar um fim: o desenvolvimento brasileiro. Neste texto, portanto, era reiterada pelo autor a defesa da utilização do capital estrangeiro como corretivo eficiente para a insuficiência de recursos internos do país. (LOVATTO, p. 141 e 142)

O contexto histórico e o clima interno do Instituto certamente não foram favoráveis às ponderações de Jaguaribe. Cinco anos antes da publicação do livro o país havia encerrado a Campanha do Petróleo é nosso com a criação da Petrobrás, empresa estatal portadora do monopólio da exploração do combustível fóssil. Segundo Nelson Werneck Sodré em $A$ verdade sobre o ISEB (SODRÉ, 1978), Jaguaribe teria sido alvo de campanha difamatória encabeçada por Alberto Guerreiro Ramos dentro do instituto. Guerreiro Ramos teria levado cópia ainda não publicada do livro $O$ nacionalismo na atualidade brasileira (JAGUARIBE, 1958b) para a diretoria da União Nacional dos Estudantes (UNE), apresentando- o como traidor da causa nacionalista 
interessado em entregar o petróleo brasileiro para o capital internacional. Esta tensão também teria se refletido no Instituto, dividindo as opinióes dos seus membros entre os dois lados envolvidos. Por fim, Hélio Jaguaribe acabou por escolher se retirar do ISEB. Encerrava-se então a militância do intelectual dentro do instituto que ele mesmo ajudara a construir.

Fazendo um balanço do nacionalismo de Hélio Jaguaribe durante sua atuação no IBESP E NO ISEB, podemos afirmar que ele se apresentava como um fenômeno histórico de consciência de uma nação em relação à sua preservação e desenvolvimento. Jaguaribe verificou que a fase de desenvolvimento de uma nação sucede uma compreensão ampla dos problemas que estrangulam o seu crescimento. Tais questóes se apresentariam de forma singular em cada país, o que torna a consciência nacionalista construtora de um pensamento genuinamente nacional.

O projeto de desenvolvimento proposto pelo intelectual era amplo, mais do que um programa econômico era um projeto de nação que articulava diversas áreas da sociedade. Para tal empreitada era necessária a participação dos setores mais modernos de todas as classes sociais. $\mathrm{O}$ argumento utilizado para essa cooperação de classes baseava-se na afirmação de que os interesses "situacionais" de cada classe convergiam para uma política desenvolvimentista, que aumentaria a renda nacional e o acesso das classes a ela através da maior produtividade. O Estado teria um papel fundamental de promover o desenvolvimento e executar esse amplo projeto de modernização nacional que passava a direcionar recursos para áreas prioritárias e a regular a iniciativa privada. Para tal, o Estado deveria ser uma esfera incólume aos "grupos de pressão" privados da sociedade, portanto, sua reforma se fazia fundamental. Hélio Jaguaribe se preocupava em estabelecer seu projeto de desenvolvimento no campo da "racionalidade técnica" para alcançar um consenso das classes sociais, tão caro ao autor, e evitar as adjetivações que o jogassem em um dos pólos das polêmicas entre "nacionalistas" e "entreguistas", marcadas pelo acirramento de bandeiras ideológicas.

O isebiano tentou passar pelo "meio" se afastando das radicalizações. Ao afirmar em 1958 que o papel do nacionalismo era de agregar harmonicamente os distintos setores sociais

de uma comunidade, estava criticando as posições nacionalistas que mais dividiam do que produziam um consenso na sociedade, uma maioria. Neste sentido tentou qualificar e legitimar o seu nacionalismo a partir do seu projeto de desenvolvimento, ao passo que criticava as posiçóes nacionalistas rasas, sem um projeto profundo e com um apelo pueril pelo que era nacional e não necessariamente bom para a nação. Nesta perspectiva, ele definiu o nacionalismo em duas categorias: "nacionalismo de meios" e "nacionalismo 
de fins”, entre as quais se incluía na segunda categoria. Portanto, o nacionalismo de Jaguaribe era coerente com o seu projeto de desenvolvimento nacional marcado pela necessidade de uma cooperação de classes, pretendendo aproximar setores mais liberais e mais estatizantes. Era pregado ao mesmo tempo o importante papel da iniciativa privada e da função primordial do Estado no planejamento.

\section{Nota}

1 Tal como veremos mais à frente neste trabalho, Hélio Jaguaribe era bastante crítico da visão que os liberais do período tinham sobre como deveria ser gerida a política e a economia. Segundo o autor, a posição neoclássica seria ultrapassada já em sua época pois não bastaria a burguesia tomar papel no desenvolvimento, mas necessitaria da ação ativa do Estado neste processo.

\section{Referências bibliográficas}

BIELSCHOWSKY, R. Pensamento econômico brasileiro: o ciclo ideológico do desenvolvimentismo. 5. ed. Rio de Janeiro: Contraponto, 2004.

CANNONE, H. M. P. Passado, desenvolvimento e futuro: a relação entre História e Política na obra de três intelectuais do ISEB. Dissertação (Mestrado). Instituto de Estudos Sociais e Políticos, Universidade do Estado do Rio de Janeiro. 2018, $114 \mathrm{f}$.

CAPUTO, A. C. \& COSTA, G. M. M. Memórias do Desenvolvimento. Ano 3, n. 3. Rio de Janeiro: Centro Internacional Celso Furtado de Políticas para o Desenvolvimento, 2009.

DRAIBE, S. Rumos e Metamorfoses. Estado e industrialização no Brasil (1930-1960). Rio de Janeiro: Paz e Terra. 2004.

FIORI, J. L. (org.). Estados e moedas no desenvolvimento das nações. Petrópolis, Vozes, 1999.

FONSECA, P. C. D. Desenvolvimento: a construção do conceito". Texto para Discussão IPEA, n.2103, julho, 2015.

GUIMARÃES, C. A. C. Vargas e Kubitschek: a longa distância entre a Petrobrás e Brasília. In: CARVALHO, M. A. R. (Org.). República no Catete. Rio de Janeiro: Museu da República, 2001.
INSTITUTO BRASILEIRO DE ECONOMIA, SOCIOLOGIA E POLÍTICA (IBESP). Para uma política nacional de desenvolvimento. In: SCHWARTZMAN, Simon (sel. e introd.). O pensamento nacionalista e os "Cadernos de Nosso Tempo". Brasília: UNB/Câmara dos Deputados, 1981. Pág.171-273.

JAGUARIBE, H. Condições institucionais do desenvolvimento. Rio de Janeiro: Ministério da educação e cultura, 1958.

JAGUARIBE, H. O nacionalismo na atualidade brasileira. Rio de Janeiro: Ministério da educação e cultura, 1958.

JAGUARIBE, H. O problema do desenvolvimento econômico e a burguesia nacional. 2 ed. São Paulo: Fórum Roberto Simonsen, 1958.

JAGUARIBE, H. A crise brasileira. In: SCHWARTZMAN, Simon (org). O Pensamento Nacionalista e os "Cadernos de Nosso Tempo". Brasília: Editora Universidade de Brasília. 1981.

JAGUARIBE, H. "Usina de altos estudos". Insight inteligência. Rio de Janeiro, n. 75, out-nov-dez 2016. p. 81-90.

JUDT, Tony. Pós-guerra: uma história da Europa desde 1945. Rio de Janeiro: Objetiva, 2007. 
LACERDA, Carlos. O poder das ideias. Rio de Janeiro: Editora Record. 1965.

LOVATTO, Angélica. A utopia nacionalista de Hélio Jaguaribe: os tempos do ISEB. São Paulo: xamã; Arte escrita, 2010.

LYNCH, C. E. C. Por que pensamento e não teoria? A imaginação político-social brasileira e o fantasma da condição periférica. Revista Dados, Rio de Janeiro, v. 56, n. 4, pp. 727-766, 2013.

MANNHEIM, K. Ideologia e Utopia. 4. ed. Rio de Janeiro: Guanabara, 1986.

MANHEIM, K. Liberdade, poder e planificação democrática. São Paulo: Mestre Jou, 1976.

MENDONÇA, S. R. Estado e economia no Brasil: opções de desenvolvimento. 3. ed. Rio de Janeiro: Graal, 1999.
MÜLLER, H. D. C. M. Hélio Jaguaribe, pensamento político em tempos isebianos: populismo, desenvolvimento nacional e nacionalismo (1952-1958) / Hugo Dante Cyro Macedo Müller. - 2019. 113f.

ORTEGA Y GASSET, José. Historia como sistema. S.d. Disponível em:

https://bit.ly/2XIYeYh. Acesso em: 17 Nov. 2020.

SANTOS, W. G. Raízes da Imaginação Política Brasileira. Revista Dados, n. 7. Rio de Janeiro, IUPERJ, 1970.

SODRÉ, N. W. A verdade sobre o ISEB. Rio de Janeiro: Avenir, 1978.

SCHUMPETER, J. Capitalismo, socialismo e democracia. Rio de Janeiro: Fundo de Cultura, 1961 .

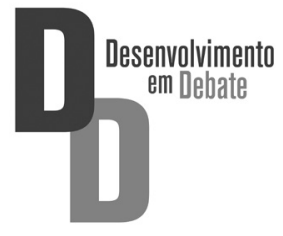

